\title{
Preindustrial nitrous oxide emissions from the land biosphere estimated by using a global biogeochemistry model
}

\author{
Rongting Xu ${ }^{1}$, Hanqin Tian ${ }^{1}$, Chaoqun $\mathrm{Lu}^{2}$, Shufen Pan $^{1,3}$, Jian Chen ${ }^{4,1}$, Jia Yang ${ }^{1}$, and Bowen Zhang ${ }^{1}$ \\ ${ }^{1}$ International Center for Climate and Global Change Research and School of Forestry and Wildlife Sciences, Auburn \\ University, Auburn, AL 36849, USA \\ ${ }^{2}$ Department of Ecology, Evolution, \& Organismal Biology, Iowa State University, Ames, IA 50011, USA \\ ${ }^{3}$ State Key Laboratory of Urban and Regional Ecology, Research Center for Eco-Environmental Sciences, Chinese Academy \\ of Sciences, Beijing 100085, China \\ ${ }^{4}$ Department of Geosciences, College of Sciences and Mathematics, Auburn University, Auburn, AL 36849, USA
}

Correspondence to: Hanqin Tian (tianhan@auburn.edu)

Received: 8 October 2016 - Discussion started: 24 October 2016

Revised: 29 May 2017 - Accepted: 24 June 2017 - Published: 28 July 2017

\begin{abstract}
To accurately assess how increased global nitrous oxide $\left(\mathrm{N}_{2} \mathrm{O}\right)$ emission has affected the climate system requires a robust estimation of the preindustrial $\mathrm{N}_{2} \mathrm{O}$ emissions since only the difference between current and preindustrial emissions represents net drivers of anthropogenic climate change. However, large uncertainty exists in previous estimates of preindustrial $\mathrm{N}_{2} \mathrm{O}$ emissions from the land biosphere, while preindustrial $\mathrm{N}_{2} \mathrm{O}$ emissions on the finer scales, such as regional, biome, or sector scales, have not been well quantified yet. In this study, we applied a processbased Dynamic Land Ecosystem Model (DLEM) to estimate the magnitude and spatial patterns of preindustrial $\mathrm{N}_{2} \mathrm{O}$ fluxes at the biome, continental, and global level as driven by multiple environmental factors. Uncertainties associated with key parameters were also evaluated. Our study indicates that the mean of the preindustrial $\mathrm{N}_{2} \mathrm{O}$ emission was approximately $6.20 \mathrm{Tg} \mathrm{N} \mathrm{yr}^{-1}$, with an uncertainty range of 4.76 to $8.13 \mathrm{Tg} \mathrm{Nyr}^{-1}$. The estimated $\mathrm{N}_{2} \mathrm{O}$ emission varied significantly at spatial and biome levels. South America, Africa, and Southern Asia accounted for 34.12, 23.85, and 18.93\%, respectively, together contributing $76.90 \%$ of global total emission. The tropics were identified as the major source of $\mathrm{N}_{2} \mathrm{O}$ released into the atmosphere, accounting for $64.66 \%$ of the total emission. Our multi-scale estimates provide a robust reference for assessing the climate forcing of anthropogenic $\mathrm{N}_{2} \mathrm{O}$ emission from the land biosphere
\end{abstract}

\section{Introduction}

Nitrous oxide $\left(\mathrm{N}_{2} \mathrm{O}\right)$ acts as the third most important greenhouse gas (GHG) after carbon dioxide $\left(\mathrm{CO}_{2}\right)$ and methane $\left(\mathrm{CH}_{4}\right)$, contributing greatly to the current radiative forcing (Myhre et al., 2013). Nitrous oxide is also the most longlived reactant, resulting in the destruction of stratospheric ozone (Prather et al., 2015; Ravishankara et al., 2009). The atmospheric concentration of $\mathrm{N}_{2} \mathrm{O}$ has increased from 275 to 329 parts per billion (ppb) since the preindustrial era until 2015 at a rate of approximately $0.26 \%$ per year, as a result of human activities (Davidson, 2009; Forster et al., 2007; NOAA2006A, 2016). The human-induced $\mathrm{N}_{2} \mathrm{O}$ emissions from the terrestrial biosphere have offset about $50 \%$ of terrestrial $\mathrm{CO}_{2}$ sink and contributed a net warming effect on the climate system (Tian et al., 2016). In the contemporary period, anthropogenic $\mathrm{N}_{2} \mathrm{O}$ emissions are mainly caused by the expansion of agricultural land area and an increase in nitrogen $(\mathrm{N})$ fertilizer application, as well as industrial activities, biomass burning, and indirect emissions from reactive N (Galloway et al., 2004; Reay et al., 2012). Human-induced biogenic $\mathrm{N}_{2} \mathrm{O}$ emissions were calculated by subtracting the preindustrial emissions (Tian et al., 2016), even though a small amount of anthropogenic $\mathrm{N}_{2} \mathrm{O}$ emissions was present before 1860, which was estimated as being $1.1 \mathrm{Tg} \mathrm{N} \mathrm{yr}^{-1}$ for 1850 by Syakila and Kroeze (2011) and 0.7 (0.6-0.8) $\mathrm{Tg} \mathrm{N} \mathrm{yr}^{-1}$ (including anthropogenic biogenic emissions from soils and biomass burning) for 1860 by David- 
son (2009). Therefore, it is necessary to provide a robust reference of preindustrial $\mathrm{N}_{2} \mathrm{O}$ emission for assessing the climate forcing of anthropogenic $\mathrm{N}_{2} \mathrm{O}$ emission from the land biosphere.

Numerous studies have reported the sources and estimates of $\mathrm{N}_{2} \mathrm{O}$ emission since the preindustrial era (Davidson and Kanter, 2014; Galloway et al., 2004; Kroeze et al., 1999; Prather et al., 2012, 2015; Syakila and Kroeze, 2011). According to the Intergovernmental Panel on Climate Change Guidelines (IPCC, 1997), the global $\mathrm{N}_{2} \mathrm{O}$ emission evaluated by Kroeze et al. (1999) is $11(8-13) \mathrm{Tg} \mathrm{N} \mathrm{yr}^{-1}$ (natural soils: 5.6-6.6 $\mathrm{Tg} \mathrm{N} \mathrm{yr}^{-1}$; anthropogenic: $1.4 \mathrm{Tg} \mathrm{N} \mathrm{yr}^{-1}$ ), which is consistent with the estimation from global preagricultural $\mathrm{N}_{2} \mathrm{O}$ emissions in soils $\left(6-7 \mathrm{Tg} \mathrm{N} \mathrm{yr}^{-1}\right.$ ) (Bouwman et al., 1993). While taking into account the new emission factor from the IPCC 2006 Guidelines (Denman et al., 2007), Syakila and Kroeze (2011) conducted an updated estimate based on the study of Kroeze et al. (1999) and reported that the global preindustrial $\mathrm{N}_{2} \mathrm{O}$ emission is $11.6 \mathrm{Tg} \mathrm{N} \mathrm{yr}^{-1}$ (anthropogenic: $1.1 \mathrm{Tg} \mathrm{N} \mathrm{yr}^{-1}$; natural soils: $7 \mathrm{Tg} \mathrm{N} \mathrm{yr}^{-1}$ ). Based on the IPCC AR5, Davidson and Kanter (2014) indicated that the central estimates of both top-down and bottom-up approaches for preindustrial natural emissions were in agreement at $11(10-12) \mathrm{Tg} \mathrm{Nyr}^{-1}$, including natural emission from soils at 6.6 (3.3-9.0) $\mathrm{Tg} \mathrm{N} \mathrm{yr}^{-1}$ (Syakila and Kroeze, 2011). Prather et al. (2015) provided an estimate of the preindustrial emissions (total natural emission: $10.5 \mathrm{Tg} \mathrm{N} \mathrm{yr}^{-1}$ ) based on the most recent study with a corrected lifetime of $116 \pm 9$ years. Although these previous estimates intend to provide a baseline of preindustrial $\mathrm{N}_{2} \mathrm{O}$ emission at a global level, information on preindustrial $\mathrm{N}_{2} \mathrm{O}$ emissions at fine resolutions such as biome, sector or country, and regional levels remains unknown but is needed for climate change mitigation.

Large uncertainties in the estimates of preindustrial $\mathrm{N}_{2} \mathrm{O}$ emission could derive from different approaches (i.e., topdown and bottom-up), as mentioned above. Nitrous oxide, as an important component of the $\mathrm{N}$ cycle, is produced by biological processes such as denitrification and nitrification in terrestrial and aquatic systems (Schmidt et al., 2004; Smith and Arah, 1990; Wrage et al., 2001). In order to accurately estimate preindustrial $\mathrm{N}_{2} \mathrm{O}$ emissions using the processbased Dynamic Land Ecosystem Model (DLEM; Tian et al., 2010), uncertainties associated with key parameters, such as maximum nitrification and denitrification rates, biological $\mathrm{N}$ fixation (BNF) rates, and the adsorption coefficient for soil ammonium $\left(\mathrm{NH}_{4}^{+}\right)$and nitrate $\left(\mathrm{NO}_{3}^{-}\right)$, were required to be considered in model simulation. Upper and lower limits of these parameters were used to derive a range of preindustrial $\mathrm{N}_{2} \mathrm{O}$ emissions from terrestrial ecosystems.

In this study, the DLEM was used to simulate global $\mathrm{N}_{2} \mathrm{O}$ emission in the preindustrial era at a resolution of $0.5^{\circ} \times 0.5^{\circ}$ latitude $\times$ longitude. Since there are no observational data of $\mathrm{N}_{2} \mathrm{O}$ emission in the preindustrial period, the estimates of natural emission from Prather et al. $(2012,2015)$ were used to validate the simulation results. In addition, site-level $\mathrm{N}_{2} \mathrm{O}$ emissions from different natural vegetation were used to test model performance in the contemporary period. The objectives in this study include (1) providing a global estimation of $\mathrm{N}_{2} \mathrm{O}$ emission from terrestrial soils in 1860, (2) offering the continental-, biome-, and country-scale $\mathrm{N}_{2} \mathrm{O}$ emission amounts and flux rates, and (3) discussing uncertainties in estimating $\mathrm{N}_{2} \mathrm{O}$ budget in the preindustrial era. Finally, our estimates on global and biome scales were compared with previous estimates.

\section{Methodology}

\subsection{Model description}

The DLEM is a highly integrated process-based ecosystem model, which combines biophysical characteristics, plant physiological processes, biogeochemical cycles, vegetation dynamics, and land use to make daily, spatially explicit estimates of carbon, nitrogen, and water fluxes and pool sizes in terrestrial ecosystems from site and regional to global scales (Lu and Tian, 2013; Tian et al., 2012, 2015). The DLEM is characterized of cohort structure, multiple soil layer processes, coupled carbon, water, and nitrogen cycles, multiple GHG emissions simulation, enhanced land surface processes, and dynamic linkages between terrestrial and riverine ecosystems (Liu et al., 2013; Tian et al., 2010, 2015). The previous results of GHG emissions from DLEM simulations have been validated against field observations and measurements at various sites (Lu and Tian, 2013; Ren et al., 2011; Tian et al., 2010, 2011; Zhang et al., 2016). The estimates of water, carbon, and nutrient fluxes and storage were also compared with the estimates from different approaches on regional, continental, and global scales (Pan et al., 2014; Tian et al., 2015; Yang et al., 2015). Different soil organic pools and calculations of decomposition rates have been described in Tian et al. (2015). The decomposition and nitrogen mineralization processes in the DLEM have been described in previous publications ( $\mathrm{Lu}$ and Tian, 2013; Yang et al., 2015).

\section{The $\mathrm{N}_{2} \mathrm{O}$ module}

Previous work provided a detailed description of trace gas modules in the DLEM (Tian et al., 2010). However, both denitrification and nitrification processes have been modified based on first-order kinetics (Chatskikh et al., 2005; Heinen, 2006).

In the DLEM, the $\mathrm{N}_{2} \mathrm{O}$ production and fluxes are determined by soil inorganic $\mathrm{N}$ content $\left(\mathrm{NH}_{4}^{+}\right.$and $\left.\mathrm{NO}_{3}^{-}\right)$and environmental factors, such as soil texture, temperature, and moisture:

$F_{\mathrm{N}_{2} \mathrm{O}}=\left(R_{\text {nit }}+R_{\text {den }}\right) F\left(T_{\text {soil }}\right)\left(1-F\left(Q_{\text {wfp }}\right)\right)$,

where $F_{\mathrm{N}_{2} \mathrm{O}}$ is the $\mathrm{N}_{2} \mathrm{O}$ flux from soils to the atmosphere $\left(\mathrm{g} \mathrm{N} \mathrm{m}^{2} \mathrm{~d}^{-1}\right), R_{\text {nit }}$ is the daily nitrification rate $\left(\mathrm{g} \mathrm{N} \mathrm{m}^{2} \mathrm{~d}^{-1}\right)$, 
$R_{\text {den }}$ is the daily denitrification rate $\left(\mathrm{g} \mathrm{N} \mathrm{m}^{2} \mathrm{~d}^{-1}\right), F\left(T_{\text {soil }}\right)$ is the function of daily soil temperature on nitrification process (unitless), and $F\left(Q_{\mathrm{wfp}}\right)$ is the function of water-filled porosity (unitless).

Nitrification, a process converting $\mathrm{NH}_{4}^{+}$into $\mathrm{NO}_{3}^{-}$, is simulated as a function of soil temperature, moisture, and soil $\mathrm{NH}_{4}^{+}$concentration:

$$
R_{\text {nit }}=k_{\text {nit }} F\left(T_{\text {soil }}\right) F(\psi) C_{\mathrm{NH}_{4}} \text {, }
$$

where $k_{\text {nit }}$ is the daily maximum fraction of $\mathrm{NH}_{4}^{+}$that is converted into $\mathrm{NO}_{3}^{-}$or gases $\left(\mathrm{d}^{-1}\right), F(\psi)$ is the soil moisture effect (unitless), and $C_{\mathrm{NH}_{4}}$ is the soil $\mathrm{NH}_{4}^{+}$content $\left(\mathrm{g} \mathrm{N} \mathrm{m}^{-2}\right)$. Unlike in Chatskikh et al. (2005), who set $k_{\text {nit }}$ to $0.10 \mathrm{~d}^{-1}$, $k_{\text {nit }}$ varies with different plant functional types (PFTs) in the DLEM with a range of 0.04 to $0.15 \mathrm{~d}^{-1}$. The detailed calculations of $F\left(T_{\text {soil }}\right)$ and $F(\psi)$ have been described in Pan et al. (2015) and Yang et al. (2015).

Denitrification is the process that converts $\mathrm{NO}_{3}^{-}$into three types of gases, namely, nitric oxide, $\mathrm{N}_{2} \mathrm{O}$, and dinitrogen. The denitrification rate is simulated as a function of soil temperature, water-filled porosity, and $\mathrm{NO}_{3}^{-}$concentration $C_{\mathrm{NO}_{3}}$ ( $\mathrm{g} \mathrm{N} \mathrm{g}^{-1}$ soil):

$R_{\mathrm{den}}=\alpha F\left(T_{\mathrm{soil}}\right) F\left(Q_{\mathrm{wfp}}\right) F_{\mathrm{N}}\left(C_{\mathrm{NO}_{3}}\right)$,

where $F_{\mathrm{N}}\left(C_{\mathrm{NO}_{3}}\right)$ is the dependency of the denitrification rate on $\mathrm{NO}_{3}^{-}$concentration (unitless) and $\alpha$ is the maximum denitrification rate $\left(\mathrm{g} \mathrm{N} \mathrm{m}^{-2} \mathrm{~d}^{-1}\right)$. The detailed calculations of $F\left(Q_{\mathrm{wfp}}\right), F_{\mathrm{N}}\left(C_{\mathrm{NO}_{3}}\right)$, and $\alpha$ have been described in Yang et al. (2015).

In each grid cell, there are four natural vegetation types and one crop type. The sum of $\mathrm{N}_{2} \mathrm{O}$ emission in each grid $\mathrm{d}^{-1}$ is calculated by the following formula:

$E=\sum_{i=1}^{62481} \sum_{j=1}^{5}\left(N_{i j} \times f_{i j}\right) \times A_{i} \times 10^{6} / 10^{12}$,

where $E$ is the daily sum of $\mathrm{N}_{2} \mathrm{O}$ emission from all PFTs in total grids $\left(\mathrm{Tg} \mathrm{N} \mathrm{yr}^{-1} \mathrm{~d}^{-1}\right) ; N_{i j}\left(\mathrm{~g} \mathrm{~N} \mathrm{~m}^{-2}\right)$ is the $\mathrm{N}_{2} \mathrm{O}$ emission in the grid cell $i$ for PFT $j ; f_{i j}$ is the fraction of cell used for PFT $j$ in grid cell $i$; and $A_{i}\left(\mathrm{~km}^{2}\right)$ is the area of the $i$ th grid cell. The factor $10^{6}$ converts square kilometers to square meters, and $10^{12}$ converts grams to teragrams.

\subsection{Input datasets}

Input data to drive the DLEM simulation include static and transient data (Tian et al., 2010). Several additional datasets were generated to better represent the terrestrial environment in the preindustrial period as described below. The natural vegetation map was developed based on LUH (Land Use Harmonization; Hurtt et al., 2011) and a new joint $1 \mathrm{~km}$ global land cover product (SYNMAP) (Jung et al., 2006), which rendered the fractions of 47 vegetation types in each $0.5^{\circ}$ grid. These 47 vegetation types were converted to 15 PFTs used in the DLEM through a cross-walk table (Fig. 1). Cropland distribution in 1860 was developed by aggregating the 5 arcmin resolution HYDE (History Database of the Global Environment) v3.1 global cropland distribution data (Fig. 2). Half-degree daily climate data (including average, maximum, minimum air temperature, precipitation, relative humidity, and shortwave radiation) were derived from CRU-NCEP (Climate Research Unit - National Centers for Environmental Prediction) climate forcing data (Wei et al., 2014). As a global climate dataset was not available prior to the year 1900, long-term average climate datasets from 1901 to 1930 were used to represent the initial climate state in 1860 . The nitrogen deposition dataset was developed based on the atmospheric chemistry transport model (Dentener, 2006) constrained by the EDGAR(Emission Database for Global Atmospheric Research)-HYDE nitrogen emission data (Aardenne et al., 2001). The nitrogen deposition dataset provided interannual variations in $\mathrm{NH}_{x}-\mathrm{N}$ and $\mathrm{NO}_{y}-\mathrm{N}$ deposition rates. The manure nitrogen production during 19612014 was derived by integrating the national level livestock population from FAO (http://faostat.fao.org) and the default $\mathrm{N}$ excretion rate for different livestock from IPCC 2006 Tier 1 (Zhang et al., 2017). Estimates of manure production from 1860 to 1960 were retrieved from the global estimates in Holland et al. (2005).

\subsection{Model simulation}

The implementation of the DLEM simulation includes three steps: (1) equilibrium run, (2) spin-up run, and (3) transient run. In this study, we first used a land use and land cover (LULC) map for 1860, long-term mean climate during 19011930, N input datasets for 1860 (the concentration levels of $\mathrm{N}$ deposition and manure application rate), and atmospheric $\mathrm{CO}_{2}$ in 1860 to run the model to an equilibrium state. In each grid, the equilibrium state was assumed to be reached when the interannual variations in carbon, nitrogen, and water storage were less than $0.1 \mathrm{~g} \mathrm{C} \mathrm{m}^{-2}, 0.1 \mathrm{~g} \mathrm{~N} \mathrm{~m}^{-2}$ and $0.1 \mathrm{~mm}$, respectively, during two consecutive periods of 50 years. After the model reached equilibrium state, the model was spun up by the de-trended climate data from 1901 to 1930 to eliminate system fluctuation caused by the model mode shift from the equilibrium to transient run (i.e., three spins with 10year climate data each time). Finally, the model was run in the transient mode with daily climate data, annual $\mathrm{CO}_{2}$ concentration, manure application, and $\mathrm{N}$ deposition inputs for 1860 to simulate preindustrial $\mathrm{N}_{2} \mathrm{O}$ emissions. An additional description of model initialization and the simulation procedure can be found in previous publications (Tian et al., 2010, 2011). 


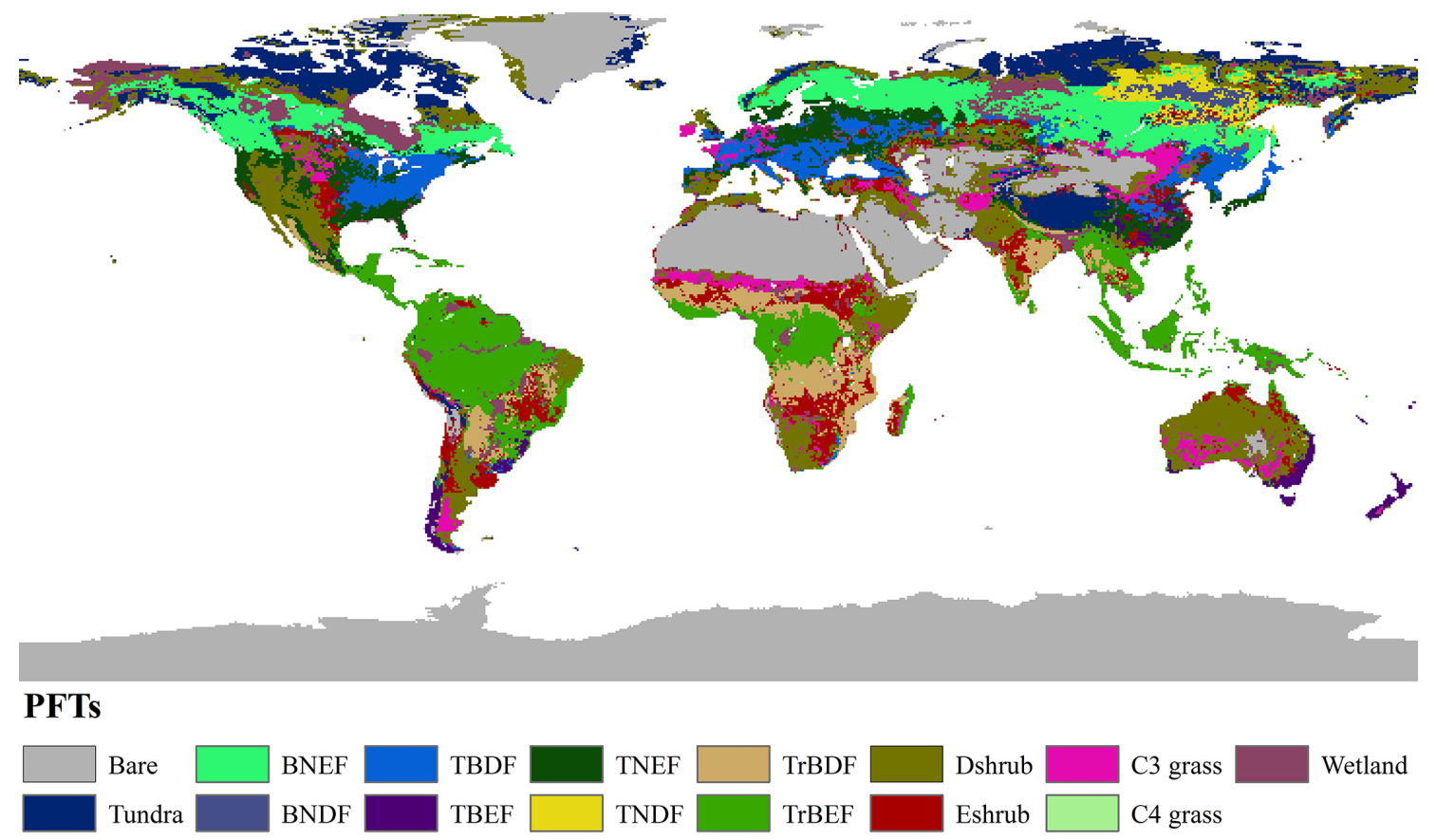

Figure 1. Global potential natural vegetation map used by DLEM in the preindustrial era. BNEF: boreal needleleaf evergreen forest; BNDF: boreal needleleaf deciduous forest; TBDF: temperate broadleaf deciduous forest; TBEF: temperate broadleaf evergreen forest; TNEF: temperate needleleaf evergreen forest; TNDF: temperate needleleaf deciduous forest; TrBDF: tropical broadleaf deciduous forest; TrBEF: tropical broadleaf evergreen forest; Dshrub: deciduous shrubland; Eshrub: evergreen shrubland.

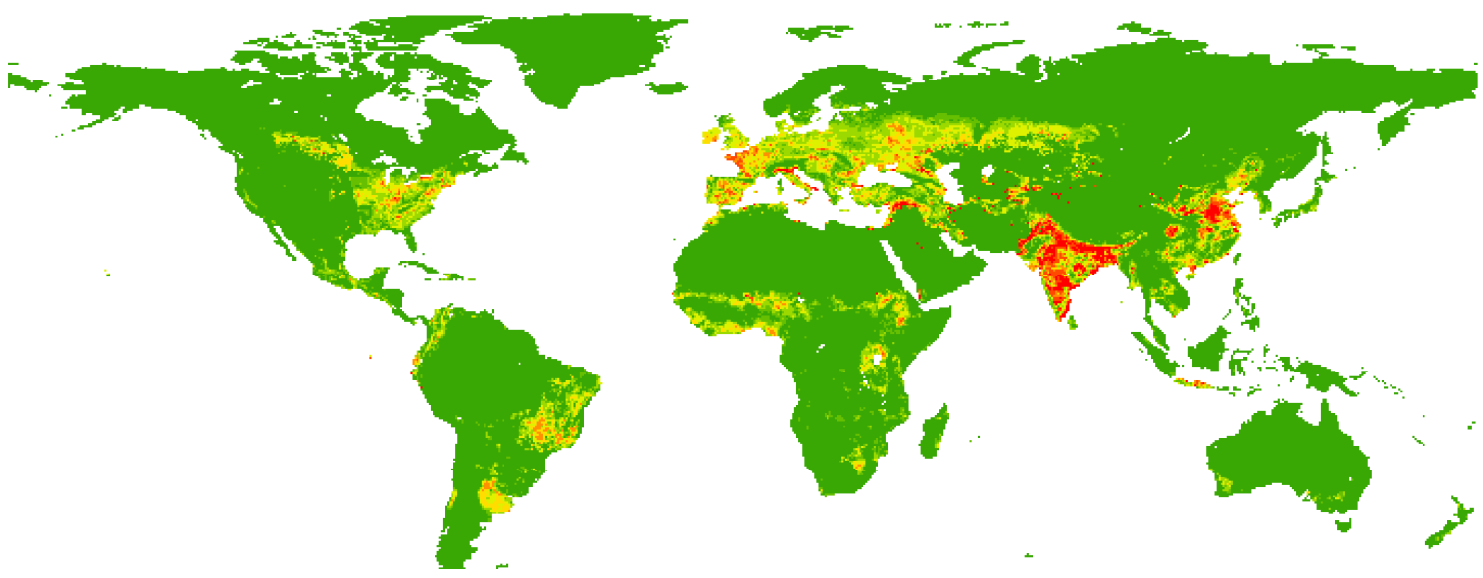

\section{Cropland area $\left(\mathrm{km}^{2}\right.$ grid $\left.^{-1}\right)$}

\begin{tabular}{|c|c|c|c|}
\hline $0-150$ & $300-600$ & $1000-1300$ & $1600-2000$ \\
\hline $150-300$ & $600-1000$ & $1300-1600$ & $>2000$ \\
\hline
\end{tabular}

Figure 2. The spatial distribution of cropland area in 1860.

\subsection{Model validation}

Observations of annual $\mathrm{N}_{2} \mathrm{O}$ emission accumulations $\left(\mathrm{g} \mathrm{N} \mathrm{m}^{-2} \mathrm{yr}^{-1}\right.$ ) were selected to compare with the simulated emissions at different sites. As there were no field measurements in the preindustrial era, observations during 1970-
2009 were collected to test the model performance in the contemporary period. All environmental factors (climate, $\mathrm{CO}_{2}$ concentration, soil property, $\mathrm{N}$ deposition, LULC) in the exact year were used as input datasets for $\mathrm{N}_{2} \mathrm{O}$ simulations. The selected sites include temperate forest, tropical forest, boreal forest, savanna, and grassland globally. As shown in Fig. 3, 


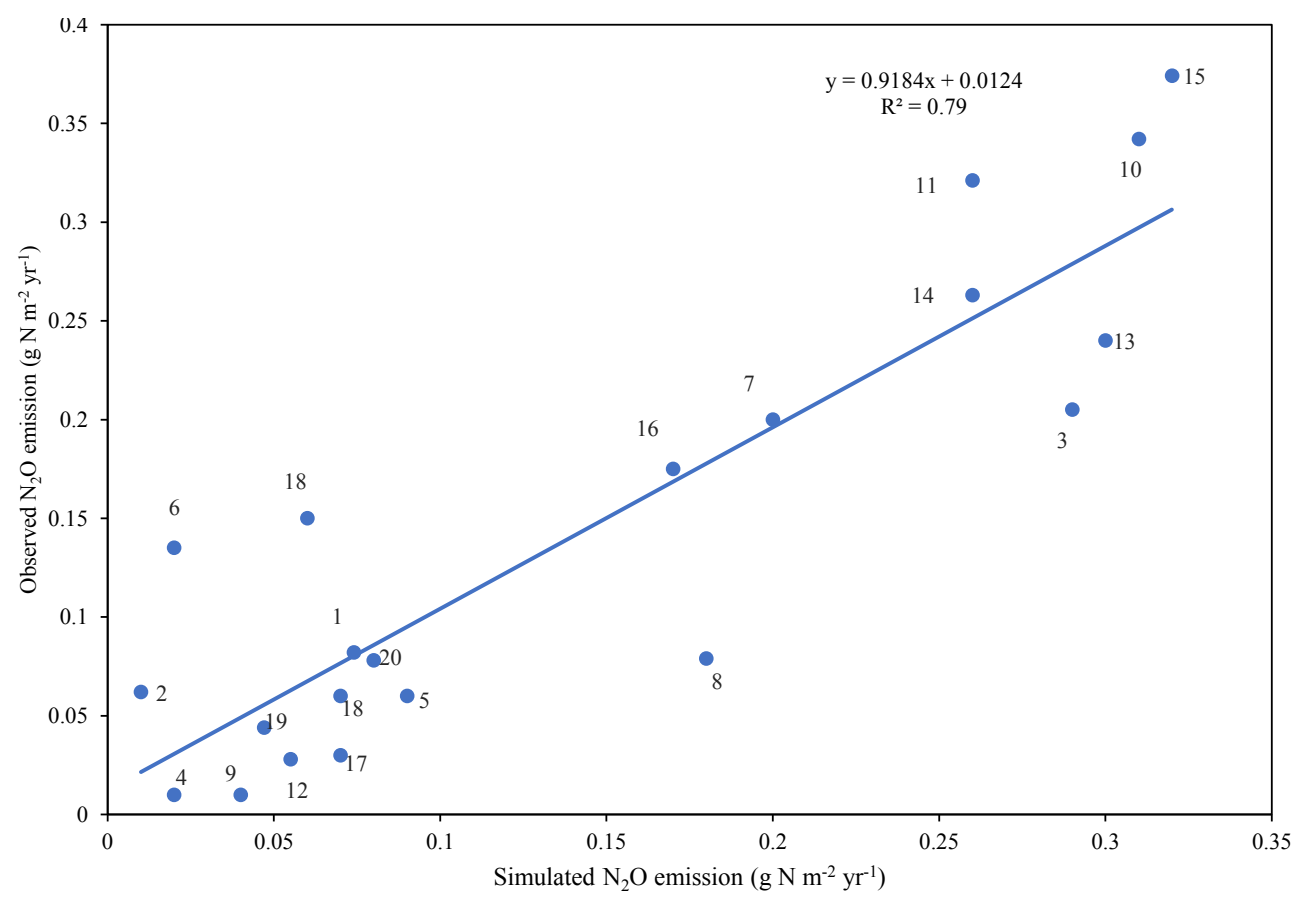

Figure 3. The comparison of the DLEM-simulated $\mathrm{N}_{2} \mathrm{O}$ emissions with field observations. All sites are described in the Supplement (Table S1).

the simulated $\mathrm{N}_{2} \mathrm{O}$ emissions have a good correlation with field observations $\left(R^{2}=0.79, p<0.001\right)$. This indicates that the DLEM has the capacity to simulate $\mathrm{N}_{2} \mathrm{O}$ emissions in the preindustrial era driven by environmental factors back then. Detailed information for each site can be found in Table S1 in the Supplement.

\subsection{Estimate of uncertainty}

In this study, uncertainties in the simulated $\mathrm{N}_{2} \mathrm{O}$ emission were evaluated through a global sensitivity and uncertainty analysis as described in Tian et al. (2011). Based on sensitivity analyses of key parameters that affect terrestrial $\mathrm{N}_{2} \mathrm{O}$ fluxes, the most sensitive parameters were identified to conduct uncertainty simulations with the DLEM. These parameters include potential denitrification and nitrification rates, $\mathrm{BNF}$ rates, and the adsorption coefficient for soil $\mathrm{NH}_{4}^{+}$and $\mathrm{NO}_{3}^{-}$(Gerber et al., 2010; Tian et al., 2015; Yang et al., 2015). The ranges of five parameters were obtained from previous studies. Chatskikh et al. (2005) set $k_{\text {nit }}$ to $0.10 \mathrm{~d}^{-1}$; however, it was set to a range of 0.04 to $0.15 \mathrm{~d}^{-1}$ and varied with different PFTs in the DLEM simulations. The uncertainty ranges of potential nitrification rates were based on previous studies (Hansen, 2002; Heinen, 2006); the global preindustrial $\mathrm{N}$ fixation was estimated to be $58 \mathrm{Tg} \mathrm{N} \mathrm{yr}^{-1}$, ranging from 50 to $100 \mathrm{Tg} \mathrm{Nyr}^{-1}$ (Vitousek et al., 2013). The spatial distribution of BNF was based on the estimates by Cleveland et al. (1999). The potential denitrification rate was set to an uncertainty range of $0.025-0.74 \mathrm{~d}^{-1}$ and varied with different PFTs in the DLEM. The uncertainty ranges of the adsorption coefficient were based on the sensitivity analysis conducted in Yang et al. (2015). Parameters used in the DLEM simulations for uncertainty analysis were assumed to follow a normal distribution. The improved Latin hypercube sampling (LHS) approach was used to randomly select an ensemble of 100 sets of parameters ( $\mathrm{R}$ version 3.2.1) (Tian et al., 2011, 2015).

In the DLEM, after the model reached equilibrium state, a spin-up run was implemented using de-trended climate data from 1901 to 1930 for each set of parameter values. Then, each set of the model was run in transient mode for 1860 to produce the result of the preindustrial $\mathrm{N}_{2} \mathrm{O}$ emissions. All results from 100 groups of simulations are shown in Table S2. The Shapiro-Wilk test was used on 100 sets of results to check the normality of DLEM simulations. It turned out that the distribution is not normal ( $P$ value $<0.05$, $\mathrm{R}$ version 3.2.1), as shown in Fig. S1 in the Supplement. Thus, the uncertainty range was represented as the minimum and maximum value of 100 sets of DLEM simulations.

\section{Results and discussion}

\subsection{Magnitude and spatial distribution of $\mathrm{N}_{2} \mathrm{O}$ emission}

The global mean preindustrial soil $\mathrm{N}_{2} \mathrm{O}$ emission was 6.20 $\mathrm{Tg} \mathrm{N} \mathrm{yr}^{-1}$. We define the parameter-induced uncertainty of our global estimates as a range between the minimum $\left(4.76 \mathrm{Tg} \mathrm{N} \mathrm{yr}^{-1}\right)$ and the maximum $\left(8.13 \mathrm{Tg} \mathrm{N} \mathrm{yr}^{-1}\right)$ of 100 


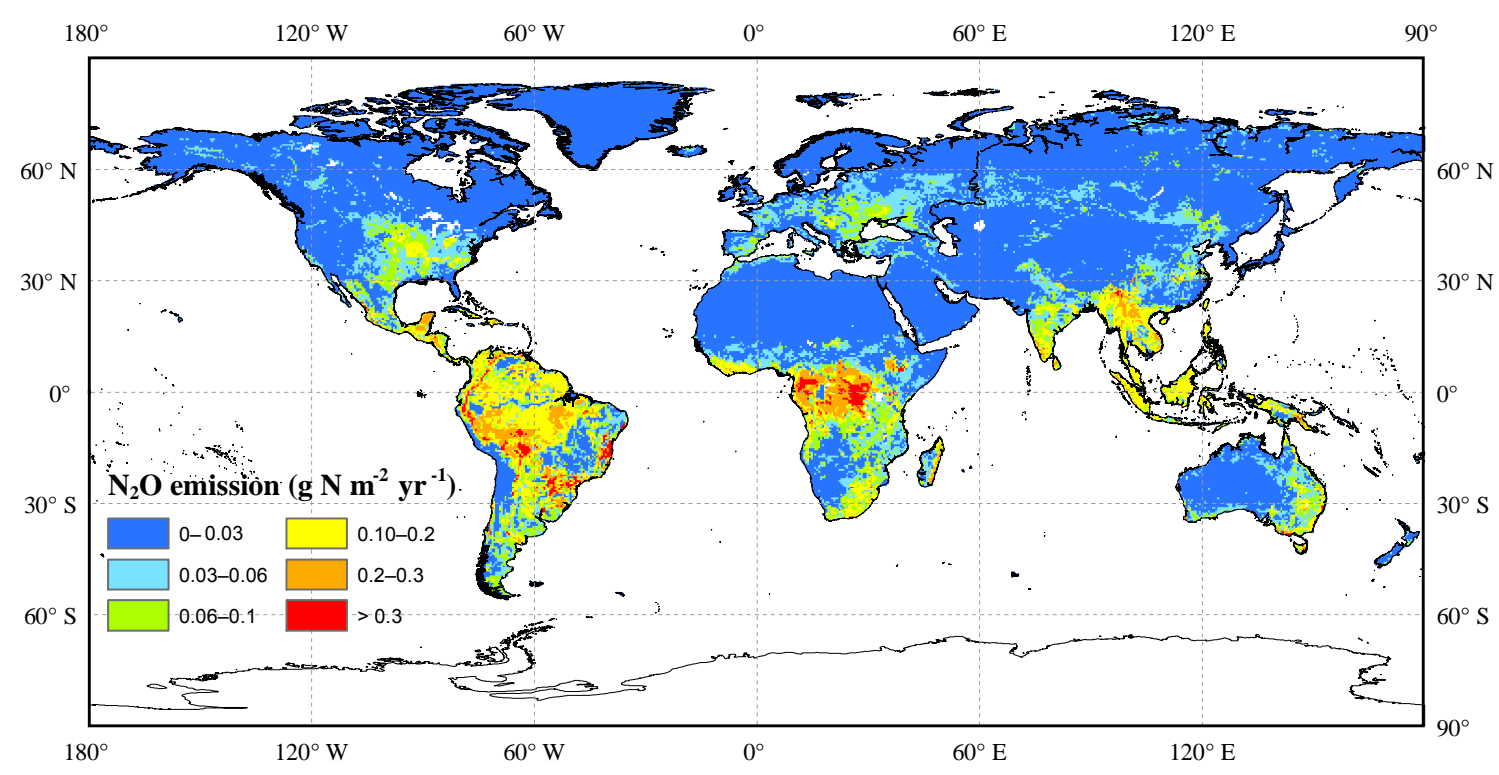

Figure 4. The spatial distribution of $\mathrm{N}_{2} \mathrm{O}$ emission in the preindustrial era.

sets of DLEM simulations. The terrestrial ecosystem in the preindustrial period acted as a source of $\mathrm{N}_{2} \mathrm{O}$, and its spatial pattern mostly depends on the biome distribution across the global land surface. The spatial distribution of annual $\mathrm{N}_{2} \mathrm{O}$ emission in a $0.5^{\circ} \times 0.5^{\circ}$ grid (Fig. 4) shows that strong sources were found near the Equator, such as Southeast Asia, central Africa, and Central America, where $\mathrm{N}_{2} \mathrm{O}$ emission reached as high as $0.45 \mathrm{~g} \mathrm{~N} \mathrm{~m}^{-2} \mathrm{yr}^{-1}$. Weak $\mathrm{N}_{2} \mathrm{O}$ sources were observed in the northern areas of North America and Asia, where the estimated $\mathrm{N}_{2} \mathrm{O}$ emission was less than $0.001 \mathrm{~g} \mathrm{~N} \mathrm{~m}^{-2} \mathrm{yr}^{-1}$. Microbial activity in soils determined the rate of nitrification and denitrification processes, which accounts for approximately $70 \%$ of global $\mathrm{N}_{2} \mathrm{O}$ emissions (Smith and Arah, 1990; Syakila and Kroeze, 2011). The tropical regions near the Equator could provide optimum temperatures and soil moistures for microbes to decompose soil organic matter and release more $\mathrm{NO}_{x}$ and $\mathrm{CO}_{2}$ into the atmosphere (Butterbach-Bahl et al., 2013). Referring to the observational data from field experiments and model simulations in the tropics, it has been argued that the tropics are the main sources within the total $\mathrm{N}_{2} \mathrm{O}$ emissions from natural vegetation (Bouwman et al., 1995; Werner et al., 2007; Zhuang et al., 2012).

In this study, Asia is divided into two parts: Southern Asia and Northern Asia, where the PFTs and climate conditions are significantly contrasting. As shown in Fig. 1, tropical forest and cropland were dominant PFTs in Southern Asia. In contrast, temperate and boreal forests were the main PFTs in Northern Asia. The estimates of $\mathrm{N}_{2} \mathrm{O}$ emissions from seven land regions are shown in Fig. 5. On continental scales, the $\mathrm{N}_{2} \mathrm{O}$ emission was $2.09(1.63-2.73) \mathrm{Tg} \mathrm{N} \mathrm{yr}^{-1}$ in South America, $1.46(1.13-1.91) \mathrm{Tg} \mathrm{N} \mathrm{yr}^{-1}$ in Africa, and $1.16(0.90-1.52) \mathrm{Tg} \mathrm{Nyr}^{-1}$ in Southern Asia. South Amer- ica, Africa, and Southern Asia accounted for 33.77, 23.60, and $18.73 \%$, respectively, together, which was $76.10 \%$ of global total emission. Europe and Northern Asia contributed $0.45(0.32-0.66) \mathrm{Tg} \mathrm{N} \mathrm{yr}^{-1}$, which was less than $10 \%$ of the total emission.

Nitrous oxide emissions varied remarkably among different ecosystems. Forest, grassland, shrub, tundra, and cropland contributed $76.90,3.11,13.14,0.18$, and $6.67 \%$, respectively, to the total emission globally (Fig. 6). In different biomes, the tropics accounted for more than half of the total $\mathrm{N}_{2} \mathrm{O}$ emission, which is comparable to the conclusion drawn by Bouwman et al. (1993). In the preindustrial era, the major inputs of reactive $\mathrm{N}$ to terrestrial ecosystems were from $\mathrm{BNF}$, which relies on the activity of a phylogenetically diverse list of bacteria, archaea, and symbioses (Cleveland et al., 1999; Vitousek et al., 2013). Tropical savannas have been considered "hot spots" of BNF by legume nodules that provide the major input of available N (Bate and Gunton, 1982). The substantial inputs of $\mathrm{N}$ into tropical forests could contribute to higher amount of gaseous $\mathrm{N}$ losses as $\mathrm{N}_{2} \mathrm{O}$ or nitrogen gas (Cleveland et al., 2010; Hall and Matson, 1999). In contrast, as the largest terrestrial biome, boreal forests lack available $\mathrm{N}$ because the rate of BNF is restricted by cold temperatures and low precipitation during the growing season (Alexander and Billington, 1986). Morse et al. (2015) conducted field experiments in northeastern North American forests. They found that denitrification does vary coherently with patterns of $\mathrm{N}$ availability in forests, and there are no significant correlations between atmospheric $\mathrm{N}$ deposition, potential net $\mathrm{N}$ mineralization, and nitrification rates. Thus, it is reasonable that boreal forests contributed the least amount of $\mathrm{N}_{2} \mathrm{O}$ emission among different forests. 

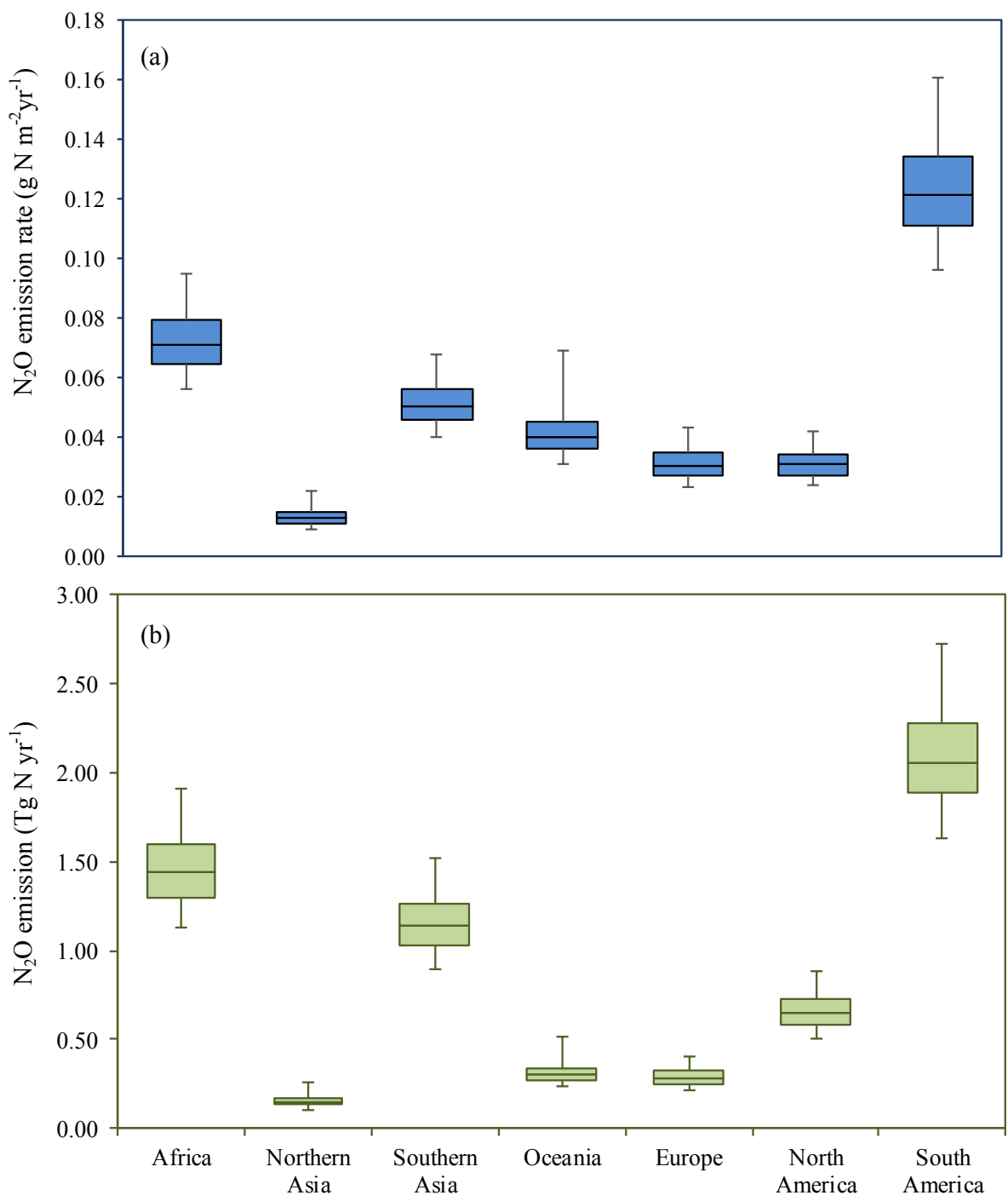

Figure 5. Estimated $\mathrm{N}_{2} \mathrm{O}$ emission rates (a) and emissions (b) with uncertainty ranges at continental level in 1860. Solid line within each box refers to the median value of $\mathrm{N}_{2} \mathrm{O}$ emission rate or amount.

As shown in Fig. 2, cropland areas varied spatially. The regions with large areas of cropland were all of Europe, India, eastern China, and the central-eastern United States. The global $\mathrm{N}_{2} \mathrm{O}$ emission from croplands was estimated as being $0.41(0.32-0.55) \mathrm{Tg} \mathrm{N} \mathrm{yr}^{-1}$, which is about 10 times less than the estimate reported in the IPCC AR5 (Ciais et al., 2014). As no synthetic $\mathrm{N}$ fertilizer was applied to the cropland in 1860, leguminous crops were the major source of $\mathrm{N}_{2} \mathrm{O}$ emission from croplands, most of which were planted in the centraleastern United States (Fig. 4). Rochette et al. (2004) conducted the experiments on the $\mathrm{N}_{2} \mathrm{O}$ emission from soybean without the application of $\mathrm{N}$ fertilizer. Their work was in agreement with the suggestion that legumes may increase $\mathrm{N}_{2} \mathrm{O}$ emissions compared with non-BNF crops (Duxbury et al., 1982) The background emission from ground-based experiments was as high as $0.31-0.42 \mathrm{~kg} \mathrm{Nha}^{-1}$ in Canada (Duxbury et al., 1982; Rochette et al., 2004).

Preindustrial $\mathrm{N}_{2} \mathrm{O}$ emission at country level could serve as a reference for calculating human-induced $\mathrm{N}_{2} \mathrm{O}$ emission in today's nations. We estimated preindustrial $\mathrm{N}_{2} \mathrm{O}$ emissions from 17 countries that are hot spots of $\mathrm{N}_{2} \mathrm{O}$ sources in the contemporary period (Table 1 ). The order of countries was based on Gerber et al. (2016) that indicated the top 17 countries in terms of total $\mathrm{N}$ application in 2000. Preindustrial $\mathrm{N}_{2} \mathrm{O}$ emissions from natural soils and croplands varied significantly on country scales. The United States, China, and India were the top countries accounting for emissions from preindustrial croplands. Countries close to or located in the tropics, such as Mexico, Indonesia, and Brazil, accounted for negligible emissions from croplands but a substantial amount from natural vegetation in the preindustrial 


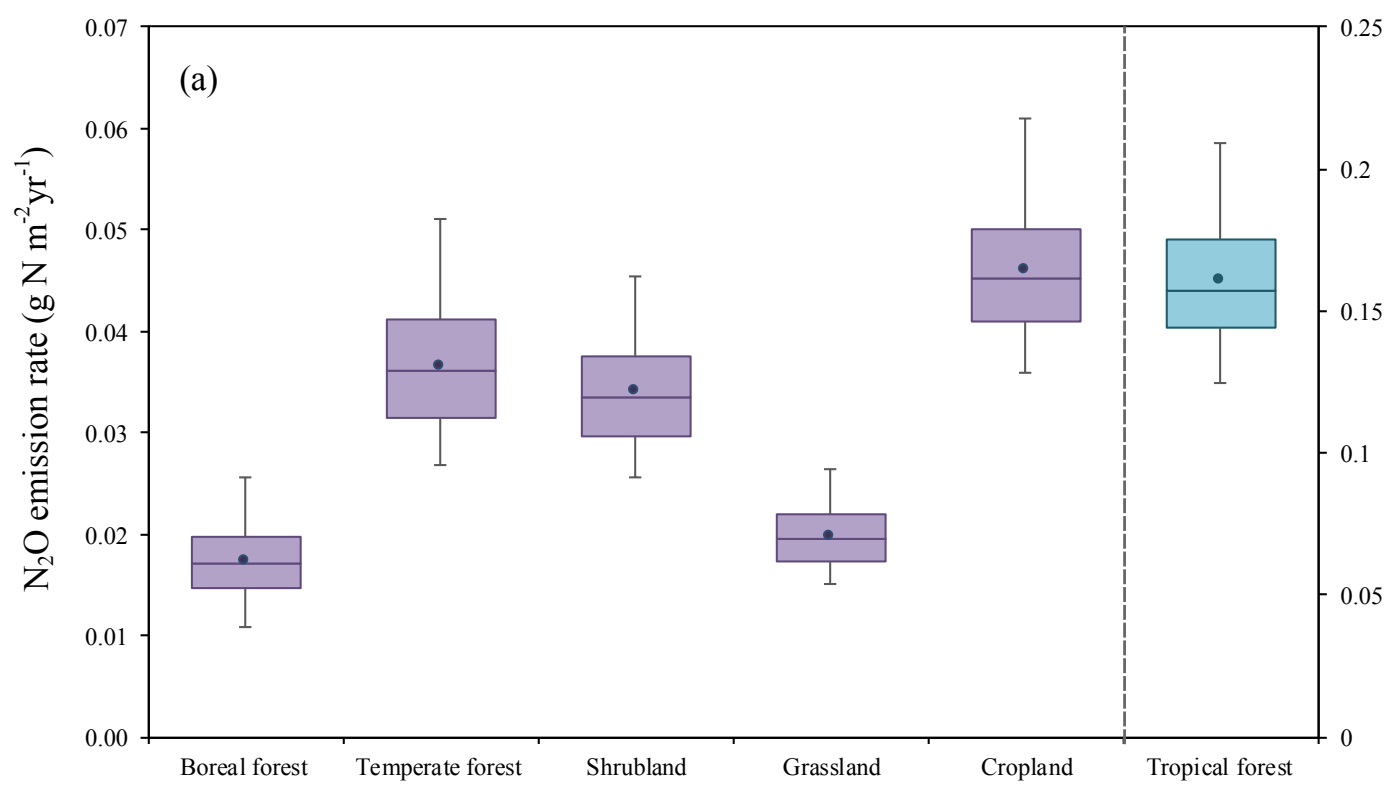

(b)

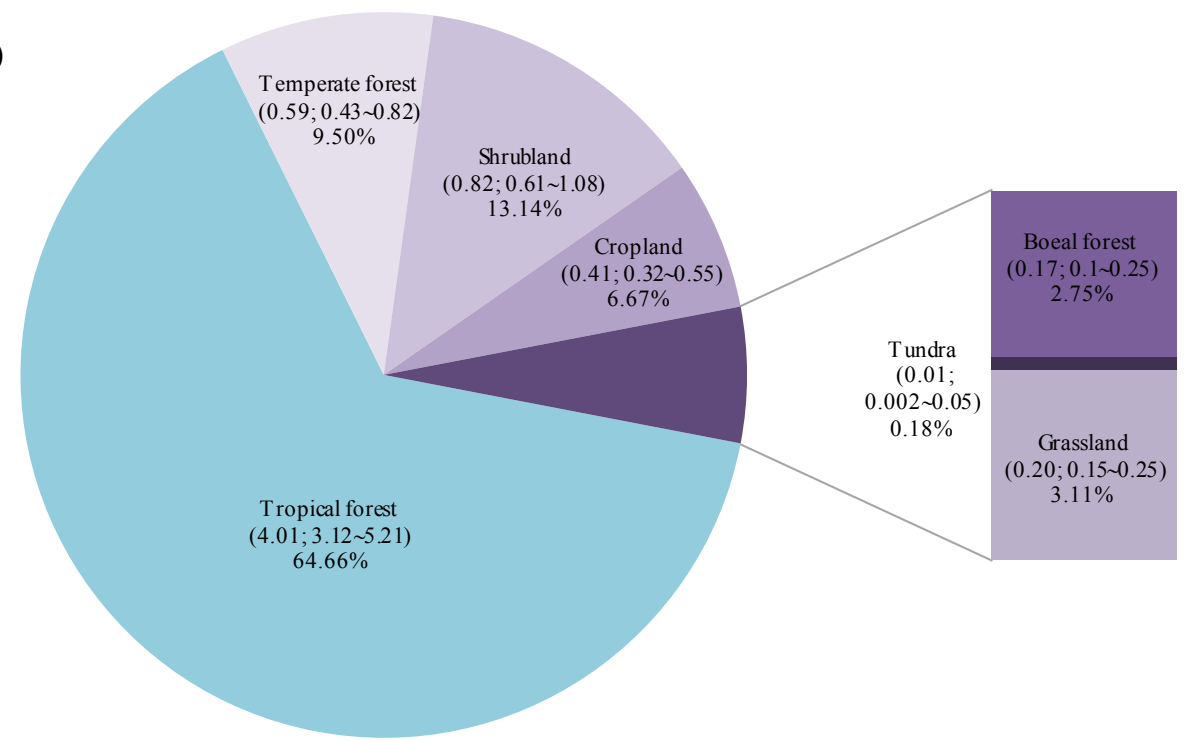

Figure 6. (a) Estimated $\mathrm{N}_{2} \mathrm{O}$ emission rate at the biome level in 1860 with the median value (solid line), the mean (solid dot), and the uncertainty range of emission rates from different biomes. The emission rate in the tundra was removed because of the extremely small value (less than $\left.0.003 \mathrm{~g} \mathrm{~N} \mathrm{~m}^{-2} \mathrm{yr}^{-1}\right)$. (b) Estimated $\mathrm{N}_{2} \mathrm{O}$ emission $\left(\mathrm{Tg} \mathrm{N} \mathrm{yr}^{-1}\right.$ ) with uncertainty ranges and its percentage (\%) at the biome level in 1860 .

era. Previous studies indicated that agriculture produces the majority of anthropogenic $\mathrm{N}_{2} \mathrm{O}$ emissions (Ciais et al., 2014; Davidson and Kanter, 2014). Our estimate on country scales could be used as a reference to quantify the net increase in $\mathrm{N}_{2} \mathrm{O}$ emissions from agriculture activities in countries of hot spots.

There is a debate about whether the natural wetlands and peatlands act as sinks or sources of $\mathrm{N}_{2} \mathrm{O}$. Previous studies showed that $\mathrm{N}_{2} \mathrm{O}$ emissions from natural peatlands are usually negligible; however, the drained peatlands with lower water tables might act as sources of $\mathrm{N}_{2} \mathrm{O}$ (Augustin et al.,
1998; Martikainen et al., 1993). High water tables in wetlands might block the activity of nitrifiers and limit the denitrification (Bouwman et al., 1993). The fluxes of $\mathrm{N}_{2} \mathrm{O}$ were negligible in the pelagic regions of boreal ponds and lakes due to the limitation of nitrification and/or nitrate inputs (Huttunen et al., 2003). Couwenberg et al. (2011) mentioned that $\mathrm{N}_{2} \mathrm{O}$ emissions always decreased after rewetting when conducting field experiments, which had been excluded from their future analysis of GHG emissions in peatlands. Hadi et al. (2005) pointed out that tropical peatlands ranged from sources to sinks of $\mathrm{N}_{2} \mathrm{O}$, highly affected by land use and hy- 
Table 1. Preindustrial $\mathrm{N}_{2} \mathrm{O}$ emissions from natural vegetation and croplands in different countries. $1 \mathrm{Mha}=10^{4} \mathrm{~km}^{2}$.

\begin{tabular}{lrrrr}
\hline Country & $\begin{array}{r}\text { Vegetation } \\
\text { area }(\mathrm{Mha})\end{array}$ & $\begin{array}{r}\text { Natural soils } \\
\left(\mathrm{Gg} \mathrm{N} \mathrm{yr}^{-1}\right)\end{array}$ & $\begin{array}{r}\text { Cropland } \\
\left(\mathrm{Gg} \mathrm{N} \mathrm{yr}^{-1}\right)\end{array}$ & $\begin{array}{r}\text { Total } \\
\left(\mathrm{Gg} \mathrm{N} \mathrm{yr}^{-1}\right)\end{array}$ \\
\hline China & 756.3 & 188 & 62 & 250 \\
India & 306.8 & 121 & 64 & 185 \\
United States & 913.9 & 296 & 81 & 377 \\
Pakistan & 65.1 & 5 & 6 & 11 \\
Indonesia & 174.1 & 181 & 2 & 183 \\
France & 52.3 & 7 & 9 & 16 \\
Brazil & 835.1 & 1017 & 11 & 1028 \\
Canada & 914.6 & 94 & 2 & 96 \\
Germany & 36.0 & 9 & 4 & 13 \\
Turkey & 74.3 & 17 & 11 & 28 \\
Mexico & 191.0 & 118 & 3 & 121 \\
Vietnam & 31.7 & 41 & 2 & 43 \\
Spain & 48.2 & 14 & 6 & 20 \\
Russian Federation & 1575.3 & 234 & 19 & 253 \\
Bangladesh & 12.4 & 2 & 5 & 7 \\
Thailand & 49.3 & 56 & 3 & 59 \\
\hline
\end{tabular}

drological zone. We were unable to examine $\mathrm{N}_{2} \mathrm{O}$ fluxes from wetlands and peatlands in 1860 as human-induced land use in those ecosystems was unknown. Thus, we excluded the $\mathrm{N}_{2} \mathrm{O}$ emissions from wetlands and peatlands in this study.

\subsection{Revisiting preindustrial global $\mathrm{N}_{2} \mathrm{O}$ emission by incorporating top-down estimates}

The "top-down" methodology used to estimate $\mathrm{N}_{2} \mathrm{O}$ emissions is based on atmospheric measurements and inversion modeling (Thompson et al., 2014). Prather et al. (2012) provided an estimate of $9.1 \pm 1.0 \mathrm{Tg} \mathrm{N} \mathrm{yr}^{-1}$ of natural emissions in the preindustrial era using observed preindustrial abundances of $270 \mathrm{ppb}$ and model estimates of lifetime decreases from 142 years in the preindustrial era to $131 \pm 10$ years in the present day. Later, Prather et al. (2015) reevaluated $\mathrm{N}_{2} \mathrm{O}$ lifetime based on Microwave Limb Sounder satellite measurements of the stratosphere, which were consistent with modeled values in the present day. The lifetime in the preindustrial era and the present day was estimated to be 123 and $116 \pm 9$ years, respectively. The current lifetime increases the preindustrial natural emission from $9.1 \pm 1.0$ to $10.5 \mathrm{Tg} \mathrm{N} \mathrm{yr}^{-1}$.

Natural sources for $\mathrm{N}_{2} \mathrm{O}$ include soil under natural vegetation, oceans, and atmospheric chemistry (Ciais et al., 2014). The emission from atmospheric chemistry was estimated as being 0.6 with an uncertainty range of $0.3-1.2 \mathrm{Tg} \mathrm{N} \mathrm{yr}^{-1}$. Syakila and Kroeze (2011) estimated global natural emissions from oceans as $3.5 \mathrm{Tg} \mathrm{N} \mathrm{yr}^{-1}$. Oceanic emission was estimated as being 3.8 with an uncertainty range of 1.8 $5.8 \mathrm{Tg} \mathrm{Nyr}^{-1}$ in the IPCC AR4. However, the uncertainty range became larger $\left(1.8-9.4 \mathrm{Tg} \mathrm{N} \mathrm{yr}^{-1}\right)$ in the IPCC AR5. In our study, the simulated $\mathrm{N}_{2} \mathrm{O}$ emission came from agri- cultural and natural soils. The natural emission was estimated as being 5.78 (4.4-7.72) $\mathrm{Tg} \mathrm{N} \mathrm{yr}^{-1}$. Combining the atmospheric chemistry and the ocean emissions in the IPCC AR5 with the natural emissions from our study, the global total natural $\mathrm{N}_{2} \mathrm{O}$ emissions were $10.18(6.5-18.32) \mathrm{Tg} \mathrm{N} \mathrm{yr}^{-1}$. The large uncertainty range was attributed to the uncertainty from oceanic emission, atmospheric chemistry emission, and our estimation. The estimated global total amount $\left(10.18 \mathrm{Tg} \mathrm{N} \mathrm{yr}^{-1}\right)$ in this study was comparable to the estimate $\left(10.5 \mathrm{Tg} \mathrm{N} \mathrm{yr}^{-1}\right.$ ) by Prather et al. (2015) using the topdown approach.

\subsection{Comparison with estimates using the bottom-up methodology}

The "bottom-up" approach includes the estimations based on inventory, statistical extrapolation of local flux measurements, and process-based modeling (Tian et al., 2016). The global preagricultural $\mathrm{N}_{2} \mathrm{O}$ emission was estimated as being $6.8 \mathrm{Tg} \mathrm{N} \mathrm{yr}^{-1}$ based on the regression relationship between measured $\mathrm{N}_{2} \mathrm{O}$ fluxes and modeled $\mathrm{N}_{2} \mathrm{O}$ production indices (Bouwman et al., 1993). This estimate was adopted to retrieve the trends of atmospheric $\mathrm{N}_{2} \mathrm{O}$ concentration in Syakila and Kroeze (2011). In our study, the preindustrial $\mathrm{N}_{2} \mathrm{O}$ emission from natural vegetation was estimated as being 5.78 (4.4-7.72) $\mathrm{Tg} \mathrm{N} \mathrm{yr}^{-1}$, which is about $1 \mathrm{Tg} \mathrm{N} \mathrm{yr}^{-1}$ lower than the estimate from Bouwman et al. (1993). An estimate from the tropics $\left( \pm 30^{\circ}\right.$ of the Equator) was about $4.57 \mathrm{Tg} \mathrm{N} \mathrm{yr}^{-1}$, which is $0.83 \mathrm{Tg} \mathrm{N} \mathrm{yr}^{-1}$ lower than the estimate from Bouwman et al. (1993). For the rest of natural vegetation, our estimate was $1.21 \mathrm{Tg} \mathrm{Nyr}^{-1}$, which is close to $1.4 \mathrm{Tg} \mathrm{N} \mathrm{yr}^{-1}$ estimated in Bouwman et al. (1993). 
Although Bouwman et al. (1993) has studied the potential $\mathrm{N}_{2} \mathrm{O}$ emission from natural soils, our study provided a first estimate of spatially distributed $\mathrm{N}_{2} \mathrm{O}$ emission in 1860 using the biogeochemical process-based model. Bouwman et al. (1993) provided $1^{\circ} \times 1^{\circ}$ monthly $\mathrm{N}_{2} \mathrm{O}$ emission using the monthly controlling factors without considering the impact of $\mathrm{N}$ deposition. In their study, the soil fertility and carbon content were constant for every month, which cannot reflect the monthly dynamic changes of carbon and $\mathrm{N}$ pools in natural soils. Moreover, although their study represented a spatial distribution of potential $\mathrm{N}_{2} \mathrm{O}$ emission from natural soils, they did not provide that estimate on biome, continent, and country scales. Thus, their result was hardly to be used as a regional reference for the net human-induced $\mathrm{N}_{2} \mathrm{O}$ emissions from some hot spots, such as Southern Asia. In contrast, in our study, using a daily climate and $\mathrm{N}$ deposition dataset better reflects the real variation in $\mathrm{N}_{2} \mathrm{O}$ emission through the growing season in natural ecosystems. The comparison with field observations during 1997-2001 indicated that the DLEM can catch the daily peak $\mathrm{N}_{2} \mathrm{O}$ emissions in Hubbard Brook Forest (Tian et al., 2010) and Inner Mongolia (Tian et al., 2011).

Regarding the $\mathrm{N}_{2} \mathrm{O}$ emission from croplands, our estimate is comparable to the estimate of $0.3(0.29-0.35) \mathrm{Tg} \mathrm{N} \mathrm{yr}^{-1}$ extracted from Syakila and Kroeze (2011) by digitizing graphs using the Getdata Graph Digitizer. In their study, the estimation was based on the relationship between the crop production and human population during 1500-1970. In contrast, the result in our study was estimated based on the cropland area of a specific crop type (mainly soybean, rice, corn, and wheat) in 1860 .

Thus, the DLEM is capable of providing an estimate of $\mathrm{N}_{2} \mathrm{O}$ emission from natural ecosystems on regional and biome scales with a higher spatial resolution. This could be a useful reference for quantifying the effects of human activities - such as LULC change, $\mathrm{N}$ fertilizer and manure application, and, increasingly, atmospheric $\mathrm{N}$ deposition - on $\mathrm{N}_{2} \mathrm{O}$ emissions in different terrestrial ecosystems or sectors in the contemporary period.

\subsection{The $\mathrm{N}_{2} \mathrm{O}$ budget in the preindustrial era}

The observed $\mathrm{N}_{2} \mathrm{O}$ concentration is the result of dynamic production and consumption processes in soils as soils act as sources or sinks of $\mathrm{N}_{2} \mathrm{O}$ through denitrification and nitrification (Chapuis-Lardy et al., 2007). There was a slight increase in atmospheric $\mathrm{N}_{2} \mathrm{O}$ concentration during 1750-1860 according to the ice core records, but these showed a rapid increase from 1860 to present (Ciais et al., 2014). Natural sources of $\mathrm{N}_{2} \mathrm{O}$ emissions have been discussed in Sect. 3.2 and 3.3. Previous studies found that there were some anthropogenic $\mathrm{N}_{2} \mathrm{O}$ emissions along with the natural sources in the preindustrial era (Davidson, 2009; Syakila and Kroeze, 2011). Syakila and Kroeze (2011) found that anthropogenic $\mathrm{N}_{2} \mathrm{O}$ emission began in 1500 because of biomass burning and agriculture. The total anthropogenic $\mathrm{N}_{2} \mathrm{O}$ emission in their study was estimated as being $1.1 \mathrm{Tg} \mathrm{N}$ in 1850 . In addition, Davidson (2009) derived a time-course analysis of sources and sinks of atmospheric $\mathrm{N}_{2} \mathrm{O}$ since 1860 . The preindustrial anthropogenic $\mathrm{N}_{2} \mathrm{O}$ sources in his study included biomass burning, agriculture (e.g., manure and fertilizer application and the cultivation of legumes) and human sewage, the sum of which was $0.7(0.6-0.8) \mathrm{Tg} \mathrm{Nyr}^{-1}$ (Davidson, 2009). Thus, anthropogenic $\mathrm{N}_{2} \mathrm{O}$ emission already existed in 1860 , but it was smaller than the contemporary amount.

Davidson (2009) mentioned that there was possibly a certain amount of $\mathrm{N}_{2} \mathrm{O}$ loss in the preindustrial period through atmospheric sink and the reduced emission from tropical deforestation. He estimated the anthropogenic sink as being $0.26 \mathrm{Tg} \mathrm{N}$ in 1860 . In addition, the deforestation of tropical forest may have caused a loss of $\mathrm{N}_{2} \mathrm{O}$ emissions in 1860 , which was estimated as being $0.03 \mathrm{Tg} \mathrm{N}$ (Davidson, 2009). However, studies have shown that the conversion of forest to pasture and cropland could increase or have no effect on $\mathrm{N}_{2} \mathrm{O}$ emissions because the effects depended on the disturbance intensity of human activities on soil conditions (van Lent et al., 2015). For instance, $\mathrm{N}_{2} \mathrm{O}$ emissions tended to increase during the first 5-10 years after conversion and thereafter might decrease to average upland forest or low canopy forest levels in the non-fertilized croplands and pastures. In contrast, emissions were at a high level during and after fertilization in fertilized croplands (van Lent et al., 2015). Thus, more work is needed to study how forest degradation affects $\mathrm{N}_{2} \mathrm{O}$ fluxes (Mertz et al., 2012).

\subsection{Future research needs}

Large uncertainty still exists in the DLEM simulation associated with the quality of input datasets and parameters applied in simulations. Although input datasets could play a significant role in the variety of the model output, it is difficult to obtain accurate datasets going back to the year 1860. Average climate data from 1901 to 1930 were used to run the model simulation, which could raise the uncertainty in estimating $\mathrm{N}_{2} \mathrm{O}$ emission in 1860 . The datasets of LULC, $\mathrm{N}$ deposition, and manure application in 1860 could introduce uncertainties into this estimate. The average oceanic and atmospheric chemistry emissions cited from the IPCC AR5 could introduce uncertainty into the calculation of the total natural emissions in 1860 when compared with the estimate done by Prather et al. (2015). Thus, a more accurate estimate of oceanic $\mathrm{N}_{2} \mathrm{O}$ emissions is significant for narrowing the confidence estimate of the preindustrial terrestrial sources. The $\mathrm{N}_{2} \mathrm{O}$ fluxes from wetlands and peat need to be included in any future study.

\section{Conclusions}

Using the process-based land ecosystem model DLEM, this study provides a spatially explicit estimate of preindustrial 
$\mathrm{N}_{2} \mathrm{O}$ emissions for major PFTs across global land surface. Improved LHS was performed to analyze uncertainty ranges of the estimates. We estimated that preindustrial $\mathrm{N}_{2} \mathrm{O}$ emission is $6.20 \mathrm{Tg} \mathrm{N} \mathrm{yr}^{-1}$. The modeled results showed a large spatial variability due to variations in climate conditions and PFTs. The tropical ecosystem was the dominant contributor of global $\mathrm{N}_{2} \mathrm{O}$ emissions. In contrast, boreal regions contributed less than $5 \%$ to the total emission. China, India, and the United States are the top countries accounting for emissions from croplands in 1860 . While uncertainties still exist in the $\mathrm{N}_{2} \mathrm{O}$ emission estimation for the preindustrial era, this study offered a relatively reasonable estimate of the preindustrial $\mathrm{N}_{2} \mathrm{O}$ emission from land soils. Moreover, this study provided a spatial estimate for $\mathrm{N}_{2} \mathrm{O}$ emission from global hot spots, which could be used as a reference to estimate net human-induced emissions in the contemporary period.

Data availability. All input data and output files used in this paper are available from the corresponding author upon request (tianhan@auburn.edu).

\section{The Supplement related to this article is available online at https://doi.org/10.5194/cp-13-977-2017-supplement.}

Author contributions. HT, SP, and RX initiated this research and designed model simulations. RX performed DLEM simulations, analyses, and calculations. CL contributed to the model calibration and data analysis. JC contributed to the data processing and statistical analysis. JY took charge of input datasets preparation (environmental factors), data description, and model verification. BZ provided manure $\mathrm{N}$ input data. All coauthors contributed to the development of the paper.

Competing interests. The authors declare that they have no conflict of interest.

Acknowledgements. This work was supported by National Key Research and Development Program of China (no. 2017YFA0604700), National Science Foundation (NSF) Grants (1243232, 121036), the Chinese Academy of Sciences STS Program (KFJ-STS-ZDTP-0), SKLURE Grant (SKLURE2017-1-6), and Auburn University IGP Program. We wish to thank the previous members in the International Center for Climate and Global Change Research, who made great contributions to the improvements of the DLEM in the past decade. We would also thank Eric A. Davidson and one anonymous reviewer who have provided thoughtful comments and suggestions, which led to a major improvement in the paper.

Edited by: Carlo Barbante

Reviewed by: E. A. Davidson and one anonymous referee

\section{References}

Aardenne, J. V., Dentener, F., Olivier, J., Goldewijk, C., and Lelieveld, J.: A $1 \times 1$ resolution data set of historical anthropogenic trace gas emissions for the period 1890-1990, Glob. Biogeochem. Cy., 15, 909-928, 2001.

Alexander, V. and Billington, M.: Nitrogen fixation in the Alaskan taiga, in: Forest ecosystems in the Alaskan taiga, Springer, New York, 112-120, 1986.

Augustin, J., Merbach, W., Steffens, L., and Snelinski, B.: Nitrous oxide fluxes of disturbed minerotrophic peatlands, Agribiol. Res., 51, 47-57, 1998.

Bate, G. and Gunton, C.: Nitrogen in the Burkea savanna, in: Ecology of tropical savannas, Springer, New York, 498-513, 1982.

Bouwman, A., Fung, I., Matthews, E., and John, J.: Global analysis of the potential for $\mathrm{N}_{2} \mathrm{O}$ production in natural soils, Glob. Biogeochem. Cy., 7, 557-597, 1993.

Bouwman, A., Van der Hoek, K., and Olivier, J.: Uncertainties in the global source distribution of nitrous oxide, J. Geophys. Res.Atmos., 100, 2785-2800, 1995.

Butterbach-Bahl, K., Baggs, E. M., Dannenmann, M., Kiese, R., and Zechmeister-Boltenstern, S.: Nitrous oxide emissions from soils: how well do we understand the processes and their controls?, Philos. T. R. Soc. B, 368, 20130122 , https://doi.org/10.1098/rstb.2013.0122, 2013.

Chapuis-Lardy, L., Wrage, N., Metay, A., CHOTTE, J. L., and Bernoux, M.: Soils, a sink for $\mathrm{N}_{2} \mathrm{O}$ ? A review, Glob. Change Biol., 13, 1-17, 2007.

Chatskikh, D., Olesen, J. E., Berntsen, J., Regina, K., and Yamulki, S.: Simulation of effects of soils, climate and management on $\mathrm{N}_{2} \mathrm{O}$ emission from grasslands, Biogeochemistry, 76, 395-419, 2005.

Ciais, P., Sabine, C., Bala, G., Bopp, L., Brovkin, V., Canadell, J., Chhabra, A., DeFries, R., Galloway, J., Heimann, M., and Jones, C.: Carbon and other biogeochemical cycles. In Climate Change 2013: The Physical Science Basis. Contribution of Working Group I to the Fifth Assessment Report of the Intergovernmental Panel on Climate Change, Cambridge University Press, Cambridge, UK, 465-570, 2014.

Cleveland, C. C., Townsend, A. R., Schimel, D. S., Fisher, H., Howarth, R. W., Hedin, L. O., Perakis, S. S., Latty, E. F., Von Fischer, J. C., and Elseroad, A.: Global patterns of terrestrial biological nitrogen $\left(\mathrm{N}_{2}\right)$ fixation in natural ecosystems, Glob. Biogeochem. Cy., 13, 623-645, 1999.

Cleveland, C. C., Houlton, B. Z., Neill, C., Reed, S. C., Townsend, A. R., and Wang, Y.: Using indirect methods to constrain symbiotic nitrogen fixation rates: a case study from an Amazonian rain forest, Biogeochemistry, 99, 1-13, 2010.

Couwenberg, J., Thiele, A., Tanneberger, F., Augustin, J., Bärisch, S., Dubovik, D., Liashchynskaya, N., Michaelis, D., Minke, M., and Skuratovich, A.: Assessing greenhouse gas emissions from peatlands using vegetation as a proxy, Hydrobiologia, 674, 6789, 2011.

Davidson, E. A.: The contribution of manure and fertilizer nitrogen to atmospheric nitrous oxide since 1860 , Nat. Geosci., 2, 659662, 2009.

Davidson, E. A. and Kanter, D.: Inventories and scenarios of nitrous oxide emissions, Environ. Res. Lett., 9, 105012, http:// iopscience.iop.org/1748-9326/9/10/105012, 2014. 
Denman, K., Brasseur, G., Chidthaisong, A., Ciais, P. M., Cox, P., Dickinson, R., Hauglustaine, D., Heinze, C., Holland, E., Jacob, D., Lohmann, U., Ramachandran, S., da Silva Dias, P., Wofsy, S., and Zhang, X.: Couplings Between Changes in the Climate System and Biogeochemistry, in: Climate Change 2007: The Physical Science Basis. Contribution of Working Group I to the Fourth Assessment Report of the Intergovernmental Panel on Climate Change, edited by: Solomon, S., Qin, D., Manning, M., Chen, Z., Marquis, M., Averyt, K. B., Tignor, M., and Miller, H., Cambridge University Press, Cambridge, UK and New York, NY, USA, 501-566, 2007.

Dentener, F.: Global maps of atmospheric nitrogen deposition, 1860, 1993, and 2050, Data set, Oak Ridge National Laboratory Distributed Active Archive Center, Oak Ridge, TN, USA, available at: http://daac.ornl.gov/ (last access: August 2015), 2006.

Duxbury, J., Bouldin, D., Terry, R., and Tate, R. L.: Emissions of nitrous oxide from soils, Nature, 298, 462-464, https://doi.org/10.1038/298462a0, 1982.

Forster, P., Ramaswamy, V., Artaxo, P., Berntsen, T., Betts, R., Fahey, D. W., Haywood, J., Lean, J., Lowe, D.C., Myhre, G. , Nganga, J., Prinn, R., Raga, G., Schulz, M., and Van Dorland, R.: Changes in Atmospheric Constituents and in Radiative Forcing, in: Climate Change 2007: The Physical Science Basis, Contribution of Working Group I to the Fourth Assessment Report of the Intergovernmental Panel on Climate Change, edited by: Solomon, S., Qin, D., Manning, M., Chen, Z., Marquis, M., Averyt, K. B., Tignor, M., and Miller, H. L., Cambridge University Press, Cambridge, United Kingdom and New York, NY, USA, 131-217, 2007.

Galloway, J. N., Dentener, F. J., Capone, D. G., Boyer, E. W., Howarth, R. W., Seitzinger, S. P., Asner, G. P., Cleveland, C., Green, P., and Holland, E.: Nitrogen cycles: past, present, and future, Biogeochemistry, 70, 153-226, 2004.

Gerber, S., Hedin, L. O., Oppenheimer, M., Pacala, S. W., and Shevliakova, E.: Nitrogen cycling and feedbacks in a global dynamic land model, Glob. Biogeochem. Cy., 24, GB1001, https://doi.org/10.1029/2008GB003336, 2010.

Gerber, J. S., Carlson, K. M., Makowski, D., Mueller, N. D., Garcia de Cortazar-Atauri, I., Havlík, P., Herrero, M., Launay, M., O'Connell, C. S., and Smith, P.: Spatially explicit estimates of $\mathrm{N}_{2} \mathrm{O}$ emissions from croplands suggest climate mitigation opportunities from improved fertilizer management, Glob. Change Biol., 22, 3383-3394, https://doi.org/10.1111/gcb.13341, 2016.

Hadi, A., Inubushi, K., Furukawa, Y., Purnomo, E., Rasmadi, M., and Tsuruta, H.: Greenhouse gas emissions from tropical peatlands of Kalimantan, Indonesia, Nutr. Cycl. Agroecosys., 71, 73 80, 2005.

Hall, S. J. and Matson, P. A.: Nitrogen oxide emissions after nitrogen additions in tropical forests, Nature, 400, 152-155, 1999.

Hansen, S.: Daisy, a flexible soil-plant-atmosphere system model, Report. Dept. Agric, The Royal Veterinary- and Agricultural University, Denmark, 2002.

Heinen, M.: Simplified denitrification models: overview and properties, Geoderma, 133, 444-463, 2006.

Holland, E., Lee-Taylor, J., Nevison, C., and Sulzman, J.: Global $\mathrm{N}$ Cycle: Fluxes and $\mathrm{N}_{2} \mathrm{O}$ mixing ratios originating from human activity, Data set, Oak Ridge National Laboratory Distributed Active Archive Center, Oak Ridge, TN, USA, available at: https://doi.org/10.3334/ORNLDAAC/797 (last access: October 2015), 2005

Holtgrieve, G. W., Jewett, P. K., and Matson, P. A.: Variations in soil $\mathrm{N}$ cycling and trace gas emissions in wet tropical forests, Oecologia, 146, 584-594, 2006.

Hurtt, G., Chini, L. P., Frolking, S., Betts, R., Feddema, J., Fischer, G., Fisk, J., Hibbard, K., Houghton, R., Janetos, A., Jones, C. D., Kindermann, G., Kinoshita, T., Goldewijk, K. K., and Riahi, K.: Harmonization of land-use scenarios for the period 1500-2100: 600 years of global gridded annual land-use transitions, wood harvest, and resulting secondary lands, Climatic Change, 109, 117-161, 2011.

Huttunen, J. T., Alm, J., Liikanen, A., Juutinen, S., Larmola, T., Hammar, T., Silvola, J., and Martikainen, P. J.: Fluxes of methane, carbon dioxide and nitrous oxide in boreal lakes and potential anthropogenic effects on the aquatic greenhouse gas emissions, Chemosphere, 52, 609-621, 2003.

Intergovernmental Panel on Climate Change (IPCC): Revised 1996 IPCC Guidelines for National Greenhouse Gas Inventories vol 1/3, edited by: Houghton, J. T., Meira Filho, L. G., Lim, B., Treanton, K., Mamaty, I., Bonduki, Y., Griggs, D. J., and Callander, B. A. (London: IPCC, OECD and IEA), 1997.

Jung, M., Henkel, K., Herold, M., and Churkina, G.: Exploiting synergies of global land cover products for carbon cycle modeling, Remote Sens. Environ., 101, 534-553, 2006.

Kroeze, C., Mosier, A., and Bouwman, L.: Closing the global $\mathrm{N}_{2} \mathrm{O}$ budget: a retrospective analysis 1500-1994, Glob. Biogeochem. Cy., 13, 1-8, 1999.

Liu, M., Tian, H., Yang, Q., Yang, J., Song, X., Lohrenz, S. E., and Cai, W. J.: Long-term trends in evapotranspiration and runoff over the drainage basins of the Gulf of Mexico during 19012008, Water Resour. Res., 49, 1988-2012, 2013.

Lu, C. and Tian, H.: Net greenhouse gas balance in response to nitrogen enrichment: perspectives from a coupled biogeochemical model, Glob. Change Biol., 19, 571-588, 2013.

Martikainen, P. J., Nykänen, H., Crill, P., and Silvola, J.: Effect of a lowered water table on nitrous oxide fluxes from northern peatlands, Nature, 366, 51-53, 1993.

Mertz, O., Müller, D., Sikor, T., Hett, C., Heinimann, A., Castella, J.-C., Lestrelin, G., Ryan, C. M., Reay, D. S., Schmidt-Vogt, D., Danielsen, F., Theilade, I., Noordwijk, M. v., Verchot, L. V., Burgess, N. D., Berry, N. J., Pham, T. T., Messerli, P., Xu, J., Fensholt, R., Hostert, P., Pflugmacher, D., Bruun, T. B., Neergaard, A. D., Dons, K., Dewi, S., Rutishauser, E., and Sun, Z. L.: The forgotten D: challenges of addressing forest degradation in complex mosaic landscapes under REDD+, Geogr. Tidsskr., 112, 63-76, https://doi.org/10.1080/00167223.2012.709678, 2012.

Morse, J. L., Durán, J., Beall, F., Enanga, E. M., Creed, I. F., Fernandez, I., and Groffman, P. M.: Soil denitrification fluxes from three northeastern North American forests across a range of nitrogen deposition, Oecologia, 177, 17-27, 2015.

Myhre, G., Shindell, D., Bréon, F.-M., Collins, W., Fuglestvedt, J., Huang, J., Koch, D., Lamarque, J.-F., Lee, D., Mendoza, B., Nakajima T., Robock, A., Stephens, G., Takemura, T., and Zhang, H.: Anthropogenic and Natural Radiative Forcing, in: Climate Change 2013: The Physical Science Basis. Contribution of Working Group I to the Fifth Assessment Report of the Intergovernmental Panel on Climate Change, edited by: Stocker, T. F., Qin, D., Plattner, G.-K., Tignor, M., Allen, S. K., Boschung, 
J., Nauels, A., Xia, Y., Bex, V., and Midgley, P. M., Cambridge University Press, Cambridge, United Kingdom and New York, NY, USA, 661-684, 2013.

NOAA2006A: Combined Nitrous Oxide data from the NOAA/ESRL Global Monitoring Division, 2016.

Pan, S., Tian, H., Dangal, S. R., Zhang, C., Yang, J., Tao, B., Ouyang, Z., Wang, X., Lu, C., Ren, W., Banger, K., Yang, Q. C., Zhang, B. W., and Li, X.: Complex Spatiotemporal Responses of Global Terrestrial Primary Production to Climate Change and Increasing Atmospheric $\mathrm{CO}_{2}$ in the 21st Century, PloS One, 9, e112810, https://doi.org/10.1371/journal.pone.0112810, 2014.

Pan, S., Tian, H., Dangal, S. R., Yang, Q., Yang, J., Lu, C., Tao, B., Ren, W., and Ouyang, Z.: Responses of global terrestrial evapotranspiration to climate change and increasing atmospheric $\mathrm{CO}_{2}$ in the 21st century, Earth's Future, 3, 15-35, 2015.

Prather, M. J. and Hsu, J.: Coupling of nitrous oxide and methane by global atmospheric chemistry, Science, 330, 952-954, 2010.

Prather, M. J., Holmes, C. D., and Hsu, J.: Reactive greenhouse gas scenarios: Systematic exploration of uncertainties and the role of atmospheric chemistry, Geophys. Res. Lett., 39, L09803, https://doi.org/10.1029/2012GL051440, 2012.

Prather, M. J., Hsu, J., DeLuca, N. M., Jackman, C. H., Oman, L. D., Douglass, A. R., Fleming, E. L., Strahan, S. E., Steenrod, S. D., Søvde, O. A., Isaksen, I. S. A., Froidevaux, L., and Funke, B.: Measuring and modeling the lifetime of nitrous oxide including its variability, J. Geophys. Res.-Atmos., 120, 5693-5705, 2015.

Ravishankara, A., Daniel, J. S., and Portmann, R. W.: Nitrous oxide $\left(\mathrm{N}_{2} \mathrm{O}\right)$ : the dominant ozone-depleting substance emitted in the 21st century, Science, 326, 123-125, 2009.

Reay, D. S., Davidson, E. A., Smith, K. A., Smith, P., Melillo, J. M., Dentener, F., and Crutzen, P. J.: Global agriculture and nitrous oxide emissions, Nature Climate Change, 2, 410-416, 2012.

Ren, W., Tian, H., Xu, X., Liu, M., Lu, C., Chen, G., Melillo, J., Reilly, J., and Liu, J.: Spatial and temporal patterns of $\mathrm{CO}_{2}$ and $\mathrm{CH}_{4}$ fluxes in China's croplands in response to multifactor environmental changes, Tellus B, 63, 222-240, 2011.

Rochette, P., Angers, D. A., Bélanger, G., Chantigny, M. H., Prévost, D., and Lévesque, G.: Emissions of $\mathrm{N}_{2} \mathrm{O}$ from Alfalfa and Soybean Crops in Eastern Canada, Soil Sci. Soc. Am. J., 68, 493-506, 2004.

Schmidt, I., van Spanning, R. J., and Jetten, M. S.: Denitrification and ammonia oxidation by Nitrosomonas europaea wildtype, and NirK-and NorB-deficient mutants, Microbiology, 150, 4107-4114, 2004.

Smith, K. A. and Arah, J.: Losses of nitrogen by denitrification and emissions of nitrogen oxides from soils, Proceedings-Fertiliser Society, UK, 299 pp., 1990.

Syakila, A. and Kroeze, C.: The global nitrous oxide budget revisited, Greenhouse Gas Measurement and Management, 1, 17-26, 2011.

Thompson, R. L., Ishijima, K., Saikawa, E., Corazza, M., Karstens, U., Patra, P. K., Bergamaschi, P., Chevallier, F., Dlugokencky, E., Prinn, R. G., Weiss, R. F., O'Doherty, S., Fraser, P. J., Steele, L. P., Krummel, P. B., Vermeulen, A., Tohjima, Y., Jordan, A., Haszpra, L., Steinbacher, M., Van der Laan, S., Aalto, T., Meinhardt, F., Popa, M. E., Moncrieff, J., and Bousquet, P.: TransCom $\mathrm{N}_{2} \mathrm{O}$ model inter-comparison - Part 2: Atmospheric inversion estimates of $\mathrm{N}_{2} \mathrm{O}$ emissions, Atmos. Chem. Phys., 14, 6177-6194, https://doi.org/10.5194/acp-14-6177-2014, 2014.
Tian, H., Xu, X., Liu, M., Ren, W., Zhang, C., Chen, G., and Lu, C.: Spatial and temporal patterns of $\mathrm{CH}_{4}$ and $\mathrm{N}_{2} \mathrm{O}$ fluxes in terrestrial ecosystems of North America during 1979-2008: application of a global biogeochemistry model, Biogeosciences, 7, 2673-2694, https://doi.org/10.5194/bg-7-2673-2010, 2010.

Tian, H., Xu, X., Lu, C., Liu, M., Ren, W., Chen, G., Melillo, J., and Liu, J.: Net exchanges of $\mathrm{CO}_{2}, \mathrm{CH}_{4}$, and $\mathrm{N}_{2} \mathrm{O}$ between China's terrestrial ecosystems and the atmosphere and their contributions to global climate warming, J. Geophys. Res.-Biogeo., 116, G02011, https://doi.org/10.1029/2010JG001393, 2011.

Tian, H., Chen, G., Zhang, C., Liu, M., Sun, G., Chappelka, A., Ren, W., Xu, X., Lu, C., Pan, S., Chen, H., Hui, D.F., McNulty, S., Lockaby, Graeme, and Vance, E.: Century-scale responses of ecosystem carbon storage and flux to multiple environmental changes in the southern United States, Ecosystems, 15, 674-694, 2012.

Tian, H., Chen, G., Lu, C., Xu, X., Ren, W., Zhang, B., Banger, K., Tao, B., Pan, S., Liu, M., Zhang, C., Bruhwiler, L., and Wofsy, S.: Global methane and nitrous oxide emissions from terrestrial ecosystems due to multiple environmental changes, Ecosystem Health and Sustainability, 1, 1-20, 2015.

Tian, H., Lu, C., Ciais, P., Michalak, A. M., Canadell, J. G., Saikawa, E., Huntzinger, D. N., Gurney, K. R., Sitch, S., and Zhang, B., Yang, J., Bousquet, P., Bruhwiler, L., Chen, G., Dlugokencky, E., Friedlingstein, P., Melillo, J., Pan, S., Poulter, B., Prinn, R., Saunois, M., Schwalm, C. R., and Wofsy, S. C.: The terrestrial biosphere as a net source of greenhouse gases to the atmosphere, Nature, 531, 225-228, 2016.

van Lent, J., Hergoualc'h, K., and Verchot, L. V.: Reviews and syntheses: Soil $\mathrm{N}_{2} \mathrm{O}$ and $\mathrm{NO}$ emissions from land use and land-use change in the tropics and subtropics: a meta-analysis, Biogeosciences, 12, 7299-7313, https://doi.org/10.5194/bg-127299-2015, 2015.

Vitousek, P. M., Menge, D. N., Reed, S. C., and Cleveland, C. C.: Biological nitrogen fixation: rates, patterns and ecological controls in terrestrial ecosystems, Philos. T. Roy. Soc. B, 368, 20130119, https://doi.org/10.1098/rstb.2013.0119, 2013.

Wei, Y., Liu, S., Huntzinger, D. N., Michalak, A. M., Viovy, N., Post, W. M., Schwalm, C. R., Schaefer, K., Jacobson, A. R., Lu, C., Tian, H., Ricciuto, D. M., Cook, R. B., Mao, J., and Shi, X.: The North American Carbon Program Multi-scale Synthesis and Terrestrial Model Intercomparison Project - Part 2: Environmental driver data, Geosci. Model Dev., 7, 2875-2893, https://doi.org/10.5194/gmd-7-2875-2014, 2014.

Werner, C., Butterbach-Bahl, K., Haas, E., Hickler, T., and Kiese, R.: A global inventory of $\mathrm{N}_{2} \mathrm{O}$ emissions from tropical rainforest soils using a detailed biogeochemical model, Glob. Biogeochem. Cy., 21, GB3010, https://doi.org/10.1029/2006GB002909, 2007.

Wrage, N., Velthof, G., Van Beusichem, M., and Oenema, O.: Role of nitrifier denitrification in the production of nitrous oxide, Soil Biol. Biochem., 33, 1723-1732, 2001.

Yang, Q., Tian, H., Friedrichs, M. A., Hopkinson, C. S., Lu, C., and Najjar, R. G.: Increased nitrogen export from eastern North America to the Atlantic Ocean due to climatic and anthropogenic changes during 1901-2008, J. Geophys. Res.-Biogeo., 120, 1046-1068, 2015.

Zhang, B., Tian, H., Ren, W., Tao, B., Lu, C., Yang, J., Banger, K., and Pan, S.: Methane emissions from global rice fields: 
Magnitude, spatiotemporal patterns, and environmental controls, Global Biogeochem. Cy., 30, 1246-1263, 2016.

Zhang, B., Tian, H., Lu, C., Dangal, S. R. S., Yang, J., and Pan, S.: Manure nitrogen production and application in cropland and rangeland during 1860-2014: A 5-minute gridded global data set for Earth system modeling, Earth System Science Data Discussion, in review, https://doi.org/10.5194/essd-2017-11, 2017.
Zhuang, Q., Lu, Y., and Chen, M.: An inventory of global $\mathrm{N}_{2} \mathrm{O}$ emissions from the soils of natural terrestrial ecosystems, Atmos. Environ., 47, 66-75, 2012. 